\title{
Patient compliance with oral theophylline therapy
}

\author{
D. R. TAYLOR, C. D. KINNEY \& D. G. McDEVITT \\ Department of Therapeutics and Pharmacology, The Queen's University of Belfast and the Belfast City \\ Hospital, Northern Ireland
}

1 Day-to-day variations in plasma theophylline concentrations at steady-state have been assessed in 29 hospital inpatients who required theophylline for obstructive airways disease. Plasma concentrations were measured at $09.00 \mathrm{~h}$ and $14.00 \mathrm{~h}$ for four consecutive days in the equilibrium state in 13 patients taking $350 \mathrm{mg} /$ day and 16 patients taking 700 $\mathrm{mg} /$ day.

2 Analysis of variance gave $95 \%$ confidence limits for day-to-day variation of \pm 2.9 $\mu \mathrm{g} / \mathrm{ml}$ at $350 \mathrm{mg} /$ day and $\pm 4.8 \mu \mathrm{g} / \mathrm{ml}$ at $700 \mathrm{mg} /$ day.

3 In a separate study, compliance with sustained-release theophylline therapy has been assessed in a group of 63 patients receiving the drug in general practice but not attending hospital. Compliance was estimated by comparing plasma theophylline concentrations before and after a 7-day period of measured theophylline consumption and by tablet counting.

4 Of the 63 patients, 16 had discontinued their theophylline prior to being contacted and two did so during the first week: these were considered non-compliant.

5 Three patients had plasma concentrations which increased by more than the day-today variation for their dose level during monitored intake and one other took less than $80 \%$ of his tablets. These patients were also considered non-compliant. A further four patients in whom plasma theophylline levels were zero on at least one occasion during the study were also adjudged non-compliant.

6 Thus non-compliance with prescribed theophylline dosage occurred in $26(41.3 \%)$ of the patients studied. In the majority of these, treatment had been discontinued and the non-compliance was gross.

7 Due to normal day-to-day variations, plasma theophylline concentration measurement does not appear to be a useful method of assessing compliance in patients taking maintenance theophylline therapy.

Keywords compliance theophylline

\section{Introduction}

Theophylline is most likely to be effective as a bronchodilator when given in doses sufficient to achieve plasma concentrations in the range 10-20 $\mu \mathrm{g} / \mathrm{ml}$. Despite this, studies of patients taking maintenance theophylline therapy have shown that many of them have steady-state concentrations outside this range, most often below 10 $\mu \mathrm{g} / \mathrm{ml}$ (McDevitt et al., 1979). Amongst the factors responsible for this is intra-patient vari- ation in elimination kinetics (Upton et al., 1982) which makes optimum dose selection difficult and has resulted in plasma concentration monitoring being recommended as a regular clinical practice (Hendeles et al., 1978). Another possible explanation for low plasma drug concentrations is non-compliance with therapy, previously shown to be as high as $40-50 \%$ in a group of patients prescribed maintenance 
digoxin (Johnston \& McDevitt, 1978; McDevitt \& Johnston, 1978) and to be uninfluenced by the frequency of daily dose administration (Taggart et al., 1981).

This study was designed to evaluate the extent of non-compliance among patients with obstructive airways disease being prescribed regular oral theophylline in sustained release formulations and to investigate the usefulness of plasma theophylline concentration measurement as a means of assessment. The latter required an initial assessment of day-to-day variability in plasma theophylline levels in patients with obstructive airways disease taking slow-release theophylline preparations and known to be in the equilibrium state.

\section{Methods}

The studies were approved by the University Ethical Committee.

\section{Study 1}

This study was designed to establish the extent of day-to-day variations in plasma theophylline concentrations at steady-state in patients receiving maintenance therapy with sustained release theophylline preparations. Hospital inpatients, who required theophylline for obstructive airways disease, were studied after giving informed consent. Each patient was given oral theophylline 12-hourly in a sustained release form. After at least 3 days therapy, when the equilibrium state had been attained, plasma samples were obtained at $09.00 \mathrm{~h}$, just prior to the morning dose, and at $14.00 \mathrm{~h}$ on 4 consecutive days. The patients' clinical state was stable during the observation period and their other drug therapy was unaltered, but no attempt was made to control diet. Analysis of variance was used to compute the $95 \%$ confidence limits for within-patient day-to-day variation in plasma theophylline concentration at each of the two sampling times for the doses used.

\section{Study 2}

Names and addresses of consecutive patients who had recently been given a prescription for oral theophylline were obtained from several family practitioners. Patients with known psychiatric or terminal illnesses were excluded.

Three separate visits were made to each patient in his own home at 7-day intervals. Visits were timed to occur $4.5-6.5 \mathrm{~h}$ after the most recent dose, assuming morning administration to be at $09.00 \mathrm{~h}$ : for each patient, each visit was made at the same time. The first visit (day 1) was made unannounced. A brief explanation of the purpose of the study was made, although it was not stated that data obtained would be used to assess compliance with therapy. A careful history was taken to obtain details about the frequency and timing of drug therapy, the presence of symptoms attributable both to airways obstruction and to theophylline toxicity and the regularity with which theophylline was taken. Peak expiratory flow rate (PEFR) was measured with a Wright's Peak Flow Meter and a venous blood sample obtained. At the second visit (day 8), after repeating the questions, the PEFR and the blood sample, each patient was given a diary card and a bottle containing a known number of theophylline tablets, identical to those already prescribed. The patients were instructed to take their tablets from the bottle and to record the time on each occasion on the card. At the final visit (day 15), identical procedures were repeated. The tablet bottle was retrieved and the remaining tablets were counted: where less than $80 \%$ of the expected number had been taken, the patient was considered to be non-compliant.

Plasma samples were stored at $-20^{\circ} \mathrm{C}$ until assayed by a high performance liquid chromatography technique (Kelly \& Leahey, 1976). The coeffficient of variation for the assay was $6.6 \%$ at $4.8 \mu \mathrm{g} / \mathrm{ml}$ and $6.2 \%$ at $16.8 \mu \mathrm{g} / \mathrm{ml}$. The $95 \%$ confidence limits for variation attributable to the assay technique were \pm 0.7 and $2.2 \mu \mathrm{g} / \mathrm{ml}$ respectively at the above concentrations. Theophylline $1 \mu \mathrm{g} / \mathrm{ml}$ is equivalent to $5.5 \mu \mathrm{mol} / \mathrm{l}$.

Results are presented as the mean \pm s.e. mean.

\section{Results}

It was assumed that no important differences in bioavailability existed between the various slowrelease preparations being given to patients. These were 'Nuelin SA' (Riker Laboratories Ltd), 'Phyllocontin' (Napp Laboratories) and 'Theograd' (Abbott Laboratories). Thus no distinction was made between patients receiving the same dose of differing preparations during the study, although all patients continued to take the same formulation throughout.

\section{Study 1}

Data from a total of 29 patients were analysed. Twelve of these were obtained from a study previously reported (McDevitt et al., 1979) in which an identical protocol was used and the same theophylline assay was performed by the same investigator (CDK). The remaining 17 patients are unique to this study. Thus 13 patients received $175 \mathrm{mg}$ 12-hourly and 16 were given 350 mg 12-hourly of a sustained-release theophylline 
preparation for at least 7 days, these being commonly used clinical doses.

Over 4 days of observation at equilibrium state, in the 13 patients who received a total dose of 350 $\mathrm{mg} / \mathrm{day}$, the minimum and maximum plasma theophylline concentrations observed were 1.0 and $13.4 \mu \mathrm{g} / \mathrm{ml}$ at $09.00 \mathrm{~h}$ and 2.0 and $13.4 \mu \mathrm{g} / \mathrm{ml}$ at $14.00 \mathrm{~h}$. The maximum day-to-day variation in plasma level was $3.6 \mu \mathrm{g} / \mathrm{ml}$ at $09.00 \mathrm{~h}$ and 5.2 $\mu \mathrm{g} / \mathrm{ml}$ at $14.00 \mathrm{~h}$. The coefficients of variation in each subject ranged from 10.7 to $59.7 \%$ (mean $23.6 \%$ ) for $09.00 \mathrm{~h}$ values and from 5.2 to $36.6 \%$ (mean $22.1 \%$ ) for $14.00 \mathrm{~h}$ values. Analysis of variance gave $95 \%$ confidence limits for day-today variation of $\pm 2.9 \mu \mathrm{g} / \mathrm{ml}$.

In the 16 patients whose daily dose was 700 $\mathrm{mg} /$ day, the minimum and maximum theophylline concentrations measured were 3.7 and $22.4 \mu / \mathrm{ml}$ at $09.00 \mathrm{~h}$ and 3.7 and $23.3 \mu \mathrm{g} / \mathrm{ml}$ at $14.00 \mathrm{~h}$. The maximum day-to-day variation was $7.2 \mu \mathrm{g} / \mathrm{ml}$ at $09.00 \mathrm{~h}$ and $8.5 \mu \mathrm{g} / \mathrm{ml}$ at $14.00 \mathrm{~h}$. The coefficients of variation in each subject ranged from 10.9 to $32.8 \%$ (mean $19.9 \%$ ) for $09.00 \mathrm{~h}$ values and 6.9 to $36.7 \%$. (mean $19.0 \%$ ) for $14.00 \mathrm{~h}$ values. Analysis of variance gave $95 \%$ confidence limits of $\pm 4.8 \mu \mathrm{g} / \mathrm{ml}$.

Since the coefficient of variation attributable to intra-patient changes in plasma theophylline concentration was substantially greater than that

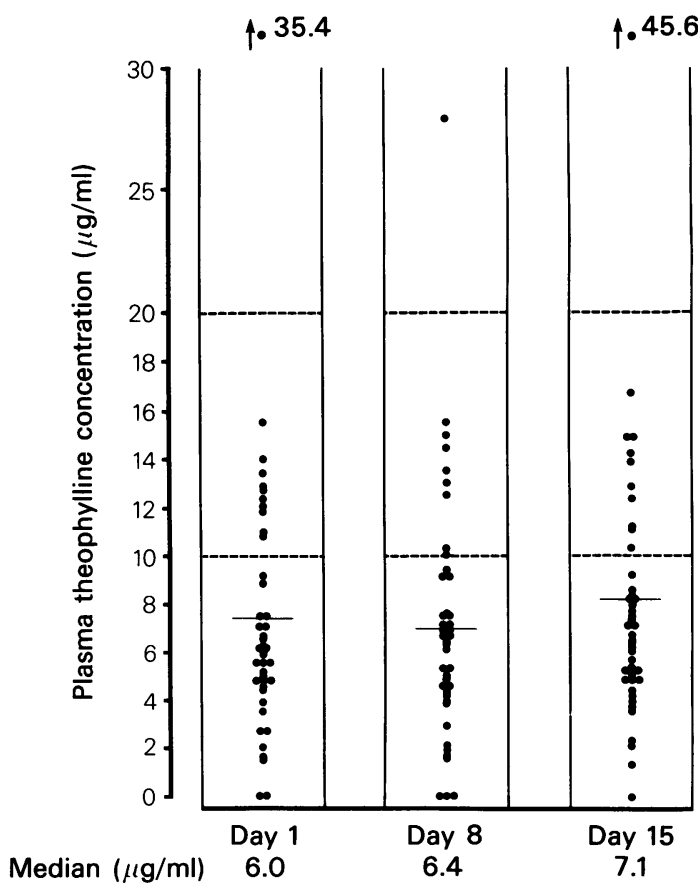

Figure 1 Plasma theophylline concentrations in 45 patients on days 1,8 and 15. Horizontal bars indicate mean concentrations. Dotted lines indicate therapeutic range. due to variation in the drug assay, the latter was ignored during the second study. From the results it was concluded that changes in plasma levels of greater than $5.8 \mu \mathrm{g} / \mathrm{ml}$ at a dose of $350 \mathrm{mg} /$ day, and of greater than $9.6 \mu \mathrm{g} / \mathrm{ml}$ at a dose of 700 $\mathrm{mg} /$ day would be required in order to conclude that a real change in drug concentration had been observed.

\section{Study 2}

One hundred and twenty-two patients' names were obtained from their general practitioner. Of these, 49 were not at home on at least two occasions when visited and no further attempts at contact were made. Four patients were unwilling to participate in the study, five were taking a rapidly absorbed theophylline preparation and one was given his medication daily by a district nurse: these 10 patients were excluded from further study.

Thus 63 patients ( 36 male, 27 female) were assessed in respect of their compliance. Their ages ranged from $24-86$ years (mean 66.9 years). Of these, one admitted to taking only occasional theophylline tablets, and a further 15 patients had stopped treatment altogether despite having renewed their prescriptions. Two other patients discontinued theophylline between days 1 and 8 of the study. Each of these patients was considered to be non-compliant.

Of the 45 patients who completed the study, the daily theophylline dosage prescribed was 350 $\mathrm{mg}$ in $26,525 \mathrm{mg}$ in two and $700 \mathrm{mg}$ in the remaining 17. The number of patients taking slow-release theophylline on a once-, twice-, three- and four-times daily basis was 5, 35, 2 and 3 respectively.

The plasma theophylline concentrations in the 45 patients on days 1,8 and 15 are shown in Figure 1. The mean plasma theophylline level on day 1 was $7.4 \pm 0.8 \mu \mathrm{g} / \mathrm{ml}$. Only 10 patients $(22.2 \%)$, all of whom were receiving $700 \mathrm{mg} /$ day, had theophylline concentrations in the range $10-20 \mu \mathrm{g} / \mathrm{ml}, 34$ patients $(75.4 \%)$ had levels below $10 \mu \mathrm{g} / \mathrm{ml}$ and 14 of these $(31.0 \%)$ were lower than $5 \mu \mathrm{g} / \mathrm{ml}$. One patient had a concentration of 35.4 $\mu \mathrm{g} / \mathrm{ml}$ without clinical evidence of toxicity. By day 8 , the mean concentration was $7.0 \pm 0.8 \mu \mathrm{g} / \mathrm{ml}$ with only eight patients $(17.8 \%)$ in the range $10-20 \mu \mathrm{g} / \mathrm{ml}$ and 36 patients (79.9\%) below 10 $\mu \mathrm{g} / \mathrm{ml}$. On day 15 , the mean theophylline concentration was $8.2 \pm 1.0 \mu \mathrm{g} / \mathrm{ml}$.

The plasma theophylline concentration did not alter significantly between days 1 and 8 , but a significant increase was observed between days 8 and $15(\mathrm{P}<0.05)$. Fewer patients had levels less than $5.0 \mu \mathrm{g} / \mathrm{ml}$ on day 15 than days 1 or 8 , but the changes were not significant (Table 1). 
Table 1 Range of plasma theophylline concentrations measured on days 1, 8 and 15 in 45 patients taking maintenance theophylline therapy

\begin{tabular}{|c|c|c|c|c|c|c|c|}
\hline \multicolumn{8}{|c|}{$\begin{array}{l}\text { Plasma concentration } \\
(\mu \mathrm{g} / \mathrm{ml})\end{array}$} \\
\hline & 0 & $0-4.9$ & $5.0-9.9$ & $10-19.9$ & $20+$ & Median & Mean \\
\hline $\begin{array}{l}\text { Day } 1 \\
\text { Number of patients } \\
(n=45)\end{array}$ & $\begin{array}{c}2 \\
(4.4 \%)\end{array}$ & $\begin{array}{c}12 \\
(26.6 \%)\end{array}$ & $\begin{array}{c}20 \\
(44.4 \%)\end{array}$ & $\begin{array}{c}10 \\
(22.2 \%)\end{array}$ & $\begin{array}{c}1 \\
(2.2 \%)\end{array}$ & 6.0 . & $\begin{array}{r}7.4 \\
\pm 0.8\end{array}$ \\
\hline $\begin{array}{l}\text { Day } 8 \\
\text { Number of patients }\end{array}$ & $\begin{array}{c}3 \\
(6.6 \%)\end{array}$ & $\begin{array}{c}14 \\
(31.1 \%)\end{array}$ & $\begin{array}{c}19 \\
(42.2 \%)\end{array}$ & $\begin{array}{c}8 \\
(17.8 \%)\end{array}$ & $(2.2 \%)$ & 6.4 & $\begin{array}{r}7.0 \\
\pm 0.8\end{array}$ \\
\hline $\begin{array}{l}\text { Day } 15 \\
\text { Number of patients }\end{array}$ & $\begin{array}{c}1 \\
(2.2 \%)\end{array}$ & $\begin{array}{c}11 \\
(24.4 \%)\end{array}$ & $\begin{array}{c}22 \\
(48.9 \%)\end{array}$ & $\begin{array}{c}10 \\
(22.2 \%)\end{array}$ & $\begin{array}{c}1 \\
(2.2 \%)\end{array}$ & 7.1 & $\begin{array}{r}8.2 \\
\pm 1.0\end{array}$ \\
\hline
\end{tabular}

Since the majority of plasma theophylline concentrations were less than $10 \mu \mathrm{g} / \mathrm{ml}$, it was not surprising that changes in theophylline concentration greater than $5.8 \mu \mathrm{g} / \mathrm{ml}$ on patients receiving $350 \mathrm{mg} /$ day and greater than $9.6 \mu \mathrm{g} / \mathrm{ml}$ on patients taking $700 \mathrm{mg} /$ day were seen in only three patients: smaller fluctuations within patients were very common. In addition, two patients had zero theophylline levels on day 1in one, this continued throughout the study, in the other the concentration rose to $6.1 \mu \mathrm{g} / \mathrm{ml}$ by day 15: two further patients had zero concentrations on day 8 only and measurable levels on days 1 and 8 . These four patients were considered to be non-compliant.

By tablet counting, only two patients took less than $80 \%$ of their prescribed dose and were adjudged non-compliant. One of these patients was also labelled non-compliant by changes in plasma theophylline concentration. A further six patients took between 80 and $90 \%$ of their tablets.
A summary of compliance status in this group of patients is shown in Table 2. Three patients were considered non-compliant because of increasing plasma theophylline concentrations on monitored theophylline therapy and one other because he took insufficient theophylline tablets. Four other patients were adjudged noncompliant because plasma theophylline levels were immeasurable on day 1 or day 8 -in one patient the level remained zero throughout the study, in another the study appeared to encourage compliance and two patients apparently ran out of tablets between days 1 and 8 . A further 18 patients had either stopped their treatment prior to the first visit or thereafter, despite recently renewing their prescriptions. This gives a total of 26 patients $(41.3 \%)$ who were not taking their prescribed theophylline dose throughout the study and must be considered non-compliant.

Of the 45 patients, 8,9 and 4 admitted on days 1,8 and 15 respectively to having missed their medication on at least one occasion during the

Table 2 Summary of non-compliance findings in 63 patients prescribed maintenance theophylline therapy

\begin{tabular}{lc}
\hline & Number of patients \\
\hline Rise in plasma theophylline concentration & $3^{*}$ \\
$<80 \%$ of tablets taken between days 8 and 15 & $2^{*}$ \\
Plasma theophylline concentration $0 \mu \mathrm{g} / \mathrm{ml}$ at & \\
$\quad$ any visit & 4 \\
Stopped treatment prior to first visit & 15 \\
Stopped treatment between days 1 and 8 & 2 \\
Admitted to only taking intermittent therapy & 1 \\
Total adjudged non-compliant & $\frac{26}{2}(41.3)$ \\
Compliant patients & $\underline{37(58.7)}$ \\
Total group & $63(100)$ \\
\hline
\end{tabular}

* 1 patient common to each group 
previous $48 \mathrm{~h}$ : of these, 5, 6 and 3 were adjudged compliant by the study criteria. Of the eight patients who were deemed to be non-compliant by plasma concentration measurement and tablet counting, three insisted that they had taken treatment regularly.

\section{Discussion}

The results of this present study indicate that more than $40 \%$ of a group of 63 patients prescribed chronic oral theophylline therapy by their general practitioners were not taking their treatment properly. Indeed the majority of the noncompliant patients were either not taking theophylline at all or were taking only occasional tablets. This level of non-compliance with treatment is comparable to that previously reported with the cardiac glycoside, digoxin, using similar techniques (Johnston \& McDevitt, 1978; McDevitt \& Johnston, 1978), and would appear to be similar to experience with other drugs investigated by a variety of methods (Haynes, 1979).

In fact, the incidence of non-compliance with theophylline therapy may be even higher than reported since this study investigated patients who were identified by recently renewing their prescriptions and, by virtue of the technique employed, excluded patients who were not at home during the day. In view of this, it is perhaps surprising to find such a large number of patients who were grossly non-compliant, that is who had discontinued their treatment or took it only occasionally (19 patients or $30.2 \%$ ). However, in a previous study of the influence of daily dose frequency on compliance with digoxin treatment, we also found that about $30 \%$ of patients were grossly unreliable, making measurements of the effects of different tablet numbers in them impossible (Taggart et al., 1981). One might have expected that a symptomatic illness such as obstructive airways disease would encourage compliance, but so many patients were receiving theophylline in amounts which produced plasma levels below $10 \mu \mathrm{g} / \mathrm{ml}$ or even below $5 \mu \mathrm{g} / \mathrm{ml}$ that it seems unlikely that failure to take the drug would result in symptomatic deterioration. It has previously been shown that, where immediate symptomatic worsening is unlikely to follow drug withdrawal, as in hypertension (Haynes, 1979) or in tuberculosis (Luntz \& Austin, 1960), drug defaulting may be common.

In contrast to experience with assessment of compliance with digoxin therapy (Johnston \&
McDevitt, 1978; McDevitt \& Johnston, 1978), measurement of plasma drug concentrations initially and after the production of 'steady-state' did not prove useful as an indicator of noncompliance with theophylline, despite confining the observations to patients who were receiving slow-release preparations which have long apparent half-lives. This would appear to be due to the wide variation in plasma theophylline concentrations achieved using a fixed dose and to the large daily fluctuations observed withinpatients at standardised times following dose administration. Thus, in order to allow for the $95 \%$ confidence limits, it was necessary to obtain plasma theophylline level changes of greater than $5.8 \mu \mathrm{g} / \mathrm{ml}$ in patients taking $350 \mathrm{mg} /$ day and 9.6 $\mu \mathrm{g} / \mathrm{ml}$ in those receiving $700 \mathrm{mg} /$ day in order to demonstrate previous non-compliance. Since the majority of patients had plasma concentrations below $10 \mu \mathrm{g} / \mathrm{ml}$ (see Figure 1), this type of technique is likely to be unrewarding in the assessment of non-compliance with theophylline, the only exception being for patients who have no drug present in plasma.

Our conclusions are at variance from those of two previous reported studies. Sublett et al. (1979) concluded that $75 \%$ of 50 asthmatic children were non-compliant because they had sub-therapeutic plasma concentrations, despite the fact that each patient was receiving a theophylline dose of only $5-6 \mathrm{mg} \mathrm{kg}^{-1} 6 \mathrm{~h}^{-1}$. In contrast to the results from this present study, Eney \& Goldstein (1976) found that monitoring patients caused more to attain therapeutic concentrations without a change in dose.

Finally, this study indicates that low plasma theophylline concentrations, unless undetectable, are more likely to result from inadequate dosage than from poor compliance. Only 11 of the 45 patients who claimed to be taking theophylline had plasma concentrations above $10 \mu \mathrm{g} / \mathrm{ml}$, and 27 of the group were taking a total daily theophylline dose of $350 \mathrm{mg}$. If the known relationship between plasma concentration and bronchodilator effect is relevant to the efficacy of chronic maintenance theophylline therapy, then it would appear that many patients are being grossly undertreated. The decision by so many patients to discontinue treatment, despite renewing their prescription, could be taken to indicate their lack of belief in the routine benefit derived. Measures to improve dose selection and ensure adequate plasma concentrations would appear to be more important than attention to factors which may affect compliance with theophylline therapy in the first instance. 


\section{References}

Eney, R. D. \& Goldstein, E. O. (1976). Compliance of chronic asthmatics with oral administration of theophylline as measured by serum and salivary levels. Pediatrics, 57, 513-517.

Haynes, R. B. (1979). The determinants of compliance: the disease and the mechanism of treatment. In Compliance in Health Care, eds Haynes, R. B., Taylor, D. W. \& Sackett, D. L., pp. 49-52. Baltimore and London: Johns Hopkins University Press.

Hendeles, L., Weinberger, M. \& Johnson, G. (1978). Monitoring serum theophylline levels. Clin. Pharmacokin., 3, 294-312.

Johnston, G. D. \& McDevitt, D. G. (1978). Digoxin compliance in patients from general practice. $B r . J$. clin. Pharmac. 6, 339-343.

Kelly, J. G. \& Leahey, W. J. (1976). Measurement of theophylline in plasma by high performance liquid chromatography. Br. J. clin. Pharmac., 3, 947-948.

Luntz, G. R. W. N. \& Austin, R. (1960). New stick test for P.A.S. in urine. Br. med. J. 1, 1679-1684.

McDevitt, D. G. \& Johnston, G. D. (1978). Digoxincompliance as a factor in drug utilisation. Adv. Pharmac. Ther., 6, 143-151.
McDevitt, D. G., Elwood, R. K. \& Russell, C. J. (1979). Why measure plasma theophylline concentrations. Curr. med. Res. Opin., 6, Suppl. 6, 26-34. Sublett, J. L., Pollard, S. J., Kadlec, G. J. \& Kanbo, J. M. (1979). Non-compliance in asthmatic children: a study of theophylline levels in a pediatric emergency room population. Ann. Allergy, 43, 95-97.

Taggart, A. J., Johnston, G. D. \& McDevitt, D. G. (1981). Does the frequency of daily dosage influence compliance with digoxin therapy. Br. J. clin. Pharmac., 1, 31-34.

Upton, R. A., Thiercelin, J. F., Guentert, G. W., Wallace, S. M., Powell, J. R., Sansom, L. and Riegelman, S. (1982). Intraindividual variability in theophylline pharmacokinetics: statistical verification in 39 of 60 healthy young adults. $J$. Pharmacokin. Biopharm., 11, 123-133.

(Received July 20, 1983, accepted September 20, 1983) 